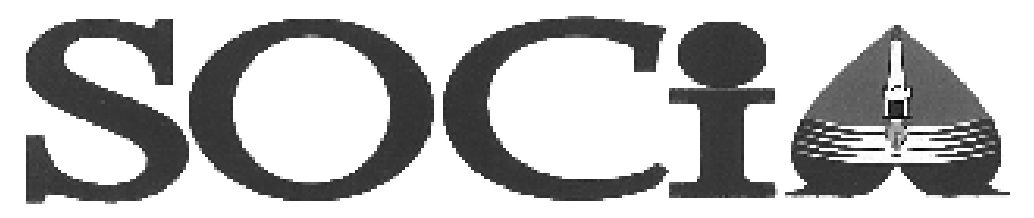

(p-ISSN) 1829-5797

(eISSN) $2549-9475$

J U R A L I L M U I L M S O I A L

Mei 2017, Vol. 14, No.1, hal 26-37

\title{
HUBUNGAN ANTARA POLA ASUH ORANG TUA DAN KEBIASAAN MENONTON TELEVISI PENDIDIKAN DENGAN NILAI-NILAI MORAL
}

Ika Noviana, Aman

\author{
Desa Dlangu RT 02/02 No. 29 Butuh Purworejo, Universitas Negeri Yogyakarta \\ ikanoviana45@gmail.com, aman@uny.ac.id
}

\begin{abstract}
Abstrak
Penelitian ini bertujuan untuk menguji: (1) hubungan antara pola asuh orang tua dengan nilai-nilai moral, (2) hubungan antara kebiasaan menonton televisi pendidikan dengan nilai-nilai moral, dan (3) hubungan antara pola asuh orang tua dan kebiasaan menonton televisi pendidikan dengan nilai-nilai moral siswa kelas V SD se-Gugus Puren Condongcatur Depok Sleman. Penelitian ini merupakan penelitian kuantitatif noneksperimental. Sampel penelitian yaitu 149 siswa kelas V SD se-Gugus Puren Condongcatur Depok Sleman. Hasil penelitian menunjukkan: (1) Terdapat hubungan yang positif dan signifikan antara pola asuh orang tua dengan nilai-nilai moral yang ditunjukkan dengan $r$ 0,812 > rtabel 0,159 dan $p<0,05$. (2) Terdapat hubungan yang positif dan signifikan antara kebiasaan menonton televisi pendidikan dengan nilai-nilai moral yang ditunjukkan dengan $r$ 0,731 > rtabel 0,159 dan $p<0,05$. (3) Terdapat hubungan yang positif dan signifikan antara pola asuh orang tua dan kebiasaan menonton televisi pendidikan dengan nilai-nilai moral yang ditunjukkan dengan $\mathrm{r}$ 0,841 > rtabel 0,159 dan F 176,828 > Ftabel 3,06. Kata kunci: pola asuh orang tua, kebiasaan menonton televisi pendidikan, nilai-nilai moral, Sekolah Dasar.

\section{Abstrak}

This study aims to examine: (1) the relationship between parenting style with moral values, (2) the relationship between habits of watching educational television with moral values, and (3) the relationship between parenting style and habits of watching educational television with moral values among fifth grade elementary school group of Puren Condongcatur Depok Sleman. This research is a nonexperimental quantitative. The research sample is 149 students of fifth grade elementary school group of Puren Condongcatur Depok Sleman. The results showed: (1) There is a positive and significant relationship between parenting style with moral values indicated by $r 0.812$ $>$ rtable 0.159 and $p<0.05$. (2) There is a positive and significant relationship between habits of watching educational television with moral values indicated by $0.731>$ rtable 0.159 and $p<0.05$. (3) There is a positive and significant relationship between parenting style and habits of watching educational television with moral values indicated by $0.841>$ rtable 0.159 and F $176.828>$ Ftable 3.06 .
\end{abstract}

Key words : parenting style, habits of watching educational television, moral values, Elementary School. 


\section{PENDAHULUAN}

Mendidik tidak hanya mencerdaskan peserta didik tetapi juga mengembangkan potensi serta menjadikan warga negara yang baik. Pendidikan moral bagi peserta didik bertujuan untuk mencapai fungsi \& tujuan pendidikan nasional. Berdasarkan Undang-Undang Nomor 20 Tahun 2003 tentang Sistem Pendidikan Nasional Pasal 3 dijelaskan bahwa, Pendidikan nasional berfungsi mengembangkan kemampuan dan membentuk watak serta peradaban bangsa yang bermartabat dalam rangka mencerdaskan kehidupan bangsa, bertujuan untuk berkembangnya potensi peserta didik agar menjadi manusia yang beriman dan bertakwa kepada Tuhan Yang Maha Esa, berakhlak mulia, sehat, berilmu, cakap, kreatif, mandiri, dan menjadi warga negara yang demokratis serta bertanggung jawab, manusia memiliki hak yang sama untuk mendapatkan pendidikan. Pendidikan tidak hanya membimbing peserta didik menjadi pandai tetapi juga menjadi pribadi yang lebih baik. Pendidikan moral sangat berperan penting dalam membimbing peserta didik tentang nilai-nilai moral yang menjadikan pribadi yang lebih baik.

Manusiahidupdenganmempertimbangkan nilai-nilai moral yang dimilikinya. Nilainilai moral membuat manusia melaksanakan apa yang sebaiknya dilakukan walaupun manusia tersebut tidak ingin melakukannya (Lickona, 2013, p.62). Manusia memiliki kewajiban untuk melakukan hal-hal yang baik berdasarkan nilai-nilai moral. Nilai-nilai moral yang dimiliki manusia akan mendukung perilaku prososial dalam pergaulan dengan teman sebaya atau lingkungan di sekitarnya.

Nilai-nilai moral merupakan hal-hal yang diinginkan atau tidak diinginkan tetapi harus dilakukan dengan benar. Nilai-nilai moral seperti nilai-nilai moral universal berlaku untuk semua orang tanpa memandang perbedaan suku, ras dan agama. Nilai-nilai moral universal merupakan nilai yang dapat diterima pada semua lingkungan dan budaya (Poerwanti, 2013, p.32). Nilai-nilai moral universal menjadi tuntutan bagi semua orang termasuk anak-anak dalam perilaku prososial di lingkungan sekitarnya. Contoh nilai-nilai moral yang berlaku secara universal dan harus dimiliki oleh anak adalah rasa hormat dan tanggung jawab.

Rasa hormat harus diberikan pada setiap interaksi dengan lingkungan sekitar. Allen \& Dennis (2009, p.595), "Respect is something that we give others, it means consideration for them and their needs as individuals." Anak memberikan rasa hormat tanpa memilih dengan siapa akan memberi hormat. Rasa hormat menjadi pertimbangan anak dalam berinteraksi dengan lingkungannya. Anak tidak bisa seenaknya memperlakukan orang lain. Rasa hormat anak haruslah diberikan kepada orang lain dalam berinteraksi sehari-hari. Anak yang memiliki sikap hormat akan terbiasa menghargai orang lain di sekolah maupun masyarakat. Anak akan menghindari diri dari sikap meremehkan orang lain dan selalu menaati peraturan yang berlaku. Rasa hormat anak dapat ditunjukkan dengan penghargaan terhadap harga diri orang lain seperti teman, guru dan orang tua.

Anak yang bertanggung jawab akan mengerjakan tugas secara sungguh-sungguh. Untuk dapat memenuhi tanggung jawab, anak harus punya kemampuan melakukan tugas atau pekerjaan (Apriani \& Wangid, 2015, p.16). Anak yang tanggung jawab akan menanggung konsekuensi dari semua yang telah ucapkan maupun yang telah dilakukan. Anak yang bertanggung jawab mengerjakan tugas dari guru maupun orang tua bahkan orang lain. Tugas yang sudah menjadi kewajiban anak akan dikerjakan secara bersungguh-sungguh jika anak memiliki tanggung jawab. Anak yang memiliki tanggung jawab senantiasa akan melaksanakan tugas dan kewajiban yang dipercayakan kepadanya. Anak yang bertanggung jawab akan menyelesaikan tugas-tugas yang diberikan secara tepat waktu. Anak akan menghindari sikap ingkar janji. Anak yang bertanggung jawab berani menanggung resiko atas sikap dan perbuatannya. Tanggung jawab dapat ditunjukkan dengan melaksanakan tugas dan kewajiban yang seharusnya dilakukan terhadap diri sendiri maupun orang lain.

Rasa hormat dan tanggung jawab me- 
wakili dasar moralitas utama yang berlaku secara universal (Lickona, 2013, p.69). Nilainilai moral universal berlaku secara universal dan memiliki konsekuensi secara universal pula. Nilai-nilai moral universal seperti rasa hormat dan tanggung jawab membuat peserta didik melaksanakan apa yang sebaiknya dilakukan karena hal tersebut benar walaupun peserta didik tidak ingin melakukannya. Pendidikan moral bagi anak sangat penting untuk mewujudkan anak yang memiliki rasa hormat dan tanggung jawab. Lingkungan sekitar anak seperti lingkungan sekolah dan keluarga berperan penting dalam pendidikan moral anak.

Sekolah dasar sebagai lembaga pendidikan anak, wajib untuk membangun manusia yang unggul dalam pengetahuan dan akhlak (Darmayanti \& Wibowo, 2014, p.224). Sekolah berperan penting dalam mendidik pengetahuan maupun moral anak. Namun, peran keluarga pun berperan penting dalam mendukung pendidikan pengetahuan dan moral anak. Sekolah dan keluarga harus bekerja sama dalam mendidik moral anak termasuk rasa hormat dan tanggung jawab. Sekolah dan orang tua tidak hanya memfasilitasi anak belajar untuk menjadi pandai. Anak-anak perlu mendapat pendidikan moral di sekolah maupun di rumah. Pentingnya dukungan lingkungan rumah terhadap usaha sekolah dalam mendidik moral anak. Anak-anak belajar dari lingkungan yang ada di sekitar termasuk lingkungan sekolah dan rumah.

Berdasarkan observasi tanggal 26 sampai dengan 30 Mei 2015 di SD se-Gugus Puren, para siswa khususnya kelas $\mathrm{V}$ menunjukkan perilaku yang bermoral. Namun, masih terdapat siswa yang menunjukkan perilaku yang kurang mencerminkan nilai-nilai moral seperti kurang menghormati teman dalam berbicara dan tidak mengerjakan tugas yang sudah menjadi kewajiban. Lingkungan sekolah sudah cukup baik dalam mendukung perkembangan moral anak dengan pendidikan moral yang diberikan kepada anak. Sekolah telah menerapkan tata tertib secara tegas dan harus dipatuhi oleh para siswa. Di lain pihak, apakah lingkungan rumah khususnya orang tua menerapkan tata tertib yang tegas dalam mendidik moral anak? Perilaku anak yang mencerminkan nilai-nilai moral tersebut apakah hasil dari pendidikan moral di sekolah saja atau terdapat dukungan dari lingkungan rumah. Apakah orang tua menjalin komunikasi yang baik dalam mendidik moral anak. Mengingat pendidikan moral yang utama bagi anak adalah lingkungan keluarga sebagai lingkungan pertama dan terdekat bagi anak.

Pendidikan moral yang diberikan di lingkungan rumah tergantung dari pola asuh orang tua dalam mengasuh anak-anaknya. Orang tua mengasuh sesuai dengan keinginan maupun pemikirannya yang dianggap tepat untuk anak sehingga orang tua tidak mengetahui pola asuh mana yang diterapkannya. Namun, terdapat tiga gaya pengasuhan atau pola asuh orang tua yang telah diidentifikasi oleh Baumrind yaitu pola asuh otoritatif (authoritative), otoriter (authoritarian), permisif (permissive) (Papalia \& Feldman, 2015, p.294). Ketiga pola asuh orang tua tersebut memiliki tingkat tinggi atau rendah dalam kontrol dan penerimaan terhadap perilaku anak. Pola asuh orang tua akan berpengaruh pada cara orang tua dalam mendidik moral anak sehingga pola asuh orang tua yang tepat menentukan nilai-nilai moral yang dimiliki anak. Pola asuh orang tua yang tepat merupakan pola asuh orang tua yang sesuai dengan kebutuhan atau pribadi anak.

Setiap pola asuh yang digunakan orang tua dalam mendidik anak-anaknya memiliki kadar tinggi atau rendah dalam mengontrol dan merespons atau menerima anak. Baumrind dalam Levine \& Munsch (2014, p.467), "Authoritative parents combine high levels of control with a good deal of warmth and encouragement." Orang tua otoritatif membuat tuntutan dan harapan yang wajar dalam mendidik moral anak sesuai dengan perkembangan anak. Orang tua otoritatif bersedia untuk memberikan alasan-alasan atau penjelasan untuk harapan dan peraturan yang dibuat. Orang tua otoritatif terbuka untuk mendengarkan pendapat dari sudut pandang anak. Terkadang anak-anak membujuk orang tua agar fleksibel tentang peraturan yang dibuat karena situasi yang menjamin. Orang tua otoritatif mem- 
perlakukan anak-anak dengan hormat dan menanggapi karakteristik unik anak-anak. Pola asuh otoritatif adalah pola asuh orang tua yang mengontrol perilaku anak secara bijak dan menghargai anak secara bijak.

Orang tua otoriter mendidik moral anak dengan menerapkan peraturan - peraturan yang tegas dan tidak boleh dilanggar oleh anak. Akinsola (2011, p.247), "Authoritarian parenting is restrictive, punitive, and places firm limits and controls on children with little or no verbal exchange." Orang tua tidak menjelaskan alasan atau tujuan dibuatnya peraturan tersebut. Tujuan orang tua otoriter untuk mendidik moral anak tentu agar anak memiliki moral yang baik. Namun, orang tua otoriter kurang berkomunikasi dengan anak apa alasan atau tujuan peraturan yang dibuat orang tua terhadap anak. Ketegasan peraturan yang dibuat orang tua otoriter bisa membuat anak patuh tetapi anak kurang memahami untuk apa anak mematuhi peraturan tersebut, sehingga anak kurang memahami pesan moral yang ingin disampaikan oleh orang tua. Pola asuh otoriter adalah pola asuh orang tua yang mengontrol perilaku anak dengan keras atau tegas dan kurang menghargai anak.

Orang tua permisif cenderung hangat, tidak terlalu mengontrol dan tidak terlalu menuntut (Papalia \& Feldman, 2015, p.294). Orang tua permisif membuat sedikit permintaan dan kurang memonitor aktivitas anak. Dalam mendidik moral anak, orang tua permisif kurang memberi tuntutan kepada anak sehingga anak bisa bernegosiasi mengenai peraturan dengan orang tua. Orang tua berdiskusi dengan anak mengenai pengambilan keputusan sehingga keputusan yang dihasilkan tidak terlalu menuntut anak. Pola asuh permisif adalah pola asuh orang tua yang kurang tegas dalam mengontrol perilaku anak dan memberikan banyak perhatian kepada anak. Orang tua permisif kurang tegas dalam mengontrol perilaku anak dan cenderung memberi banyak kehangatan terhadap anak.

Setiap orang tua yang baik akan terlibat langsung dalam mengasuh dan mendidik moral anak agar anak memiliki nilai-nilai moral.
Grant \& Ray (2013, p.63), "Children of authoritative families tend to be independent, self-reliant, and responsible and to have prosocial behaviors, such as cooperation, sharing, and sympathy for others." Hal tersebut menunjukkan adanya hubungan antara pola asuh orang tua yang diterapkan dengan nilai-nilai moral anak seperti tanggung jawab. Pola asuh yang dipilih orang tua untuk mendidik anak-anaknya akan mempengaruhi nilai-nilai moral yang dimiliki oleh anak. Pola asuh yang baik adalah pola asuh yang tepat diterapkan kepada anak sesuai dengan kebutuhan anak. Pola asuh yang tepat sesuai dengan kebutuhan anak akan mendukung nilai-nilai moral yang dimiliki anak.

Hasil penelitian menunjukkan bahwa terdapat korelasi antara pola asuh orang tua dengan perkembangan moral anak (Lacny, 2015, p.ii). Penerapan pola asuh yang tepat akan mempermudah orang tua dalam mendidik moral anak di lingkungan rumah. Namun, orang tua kurang menyadari pentingnya membangun komunikasi dua arah dengan anak. Berdasarkan wawancara pada tanggal 26 sampai dengan 30 Mei 2015 dengan siswa SD se-gugus Puren khususnya kelas V, masih terdapat orang tua yang kurang mengontrol perilaku anak. Terdapat orang tua dari siswa yang sibuk bekerja. Hal tersebut tidak menjadi masalah jika orang tua mempunyai waktu berkualitas dengan anak di sela-sela kesibukan orang tua. Orang tua dapat menasihati anak secara bijak dengan membangun komunikasi yang baik tentang perilaku-perilaku yang bermoral dalam proses mendidik moral anak. Hal tersebut harus menjadi pertimbangan bagi orang tua dalam menerapkan pola asuh yang sesuai dengan kebutuhan anak. Hasil wawancara juga menunjukkan bahwa orang tua kurang membangun komunikasi dengan anak terjadi pada kebiasaan anak dalam menonton televisi. Sebagian besar siswa kelas V SD se-gugus Puren sangatlah terbiasa menonton televisi di rumah.

Pendidikan tidak hanya diperoleh secara formal di bangku sekolah. Pendidikan juga dapat diperoleh melalui media massa berupa televisi. Televisi sudah tidak asing bagi anakanak pada masa kini. Ormrod (2012, p.124), 
"Models in the media can have an impact as well. Rather than encouraging aggression, some characters in popular media promote prosocial behaviors - those aimed at helping others rather than at enhancing one's personal well-being." Anak cenderung belajar melalui tontonan yang dilihat di televisi. Hal tersebut sesuai dengan teori pembelajaran sosial Bandura dimana anak belajar melalui apa yang dicontohkan atau secara modelling. Anak meniru adegan yang menarik atau tokoh yang menjadi idola anak.

Televisi menyajikan pengetahuan luas yang ada di dunia ini. Televisi menyajikan halhal yang bahkan tidak dapat dijumpai secara langsung sehingga banyak hal positif yang dapat dipelajari dari media televisi. Sisi terbaik televisi merupakan jendela dunia yang mengembangkan horizon intelektual, estetika dan moral (Lickona, 2013, p.568). Nilai-nilai moral dapat diperoleh melalui media televisi. Televisi tidak hanya menyajikan informasi dan hiburan saja, tetapi sebagai media pendidikan bagi anak-anak.

Program acara televisi yang mendidik sangatlah penting bagi perkembangan moral anak. Anak dapat belajar dan meniru perilaku bermoral seperti rasa hormat dan tanggung jawab yang tersaji pada acara siaran pendidikan. Acara siaran pendidikan yang disiarkan televisi adalah siaran pendidikan sekolah (school broadcasting) dan siaran pendidikan sepanjang masa (life long education) (Darwanto, 2011, p.130). Acara siaran televisi pendidikan sekolah dan sepanjang masa adalah acara atau program siaran drama maupun nondrama di saluran siaran umum yang disajikan untuk anak usia sekolah dasar.

Alloway, Williams, Jones, et al (2013, p.343), "Television is becoming an increasingly prevalent habit of a child's daily routine." Kegiatan menonton televisi merupakan kebiasaan yang sudah menjamur. Anak banyak menghabiskan waktunya setiap hari untuk menonton televisi tidak terkecuali siswa kelas V SD se-Gugus Puren. Berdasarkan wawancara pada tanggal 26 sampai dengan 30 Mei 2015 dengan siswa SD se-gugus Puren khususnya kelas
V, siswa bisa menghabiskan waktu menonton televisi sekitar 4 jam pada hari biasa dan 6-8 jam pada hari Minggu. Jika siswa rata-rata menonton televisi selama empat jam sehari, maka selama setahun siswa menghabiskan waktu menonton televisi sekitar 1.400 jam.

Banyak sekali waktu yang dihabiskan anak untuk menonton televisi. Kegiatan anak menonton televisi sudah menjadi kebiasaan sehari-hari. "In fact, the small screen has become a kind of teacher or a window to the world through which children are watching continuously and from which they extract values and models of behaviour that can be used as references in their daily lives." (Martinez \& Lopez, 2011, p.33). Orang tua sebaiknya membimbing anak agar menonton program siaran televisi pendidikan agar anak memiliki kebiasaan menonton televisi pendidikan. Anak yang terbiasa menonton program televisi pendidikan dapat belajar dan meniru nilai-nilai moral serta model yang mendidik.

Kebiasaan menonton televisi pendidikan merupakan kebiasaan anak menonton televisi yang dilakukan setiap harinya untuk menonton acara atau program-program siaran pendidikan baik program-program siaran televisi pendidikan sekolah dan sepanjang masa. Kebiasaan menonton program-program siaran televisi pendidikan sekolah adalah terbiasa menonton program siaran televisi pendidikan yang menimbulkan keinginan anak untuk menggali pengetahuan baru dan merangsang anak untuk belajar. Kebiasaan menonton program-program siaran televisi pendidikan sepanjang masa adalah terbiasa menonton program siaran televisi pendidikan yang menyajikan pengetahuan lebih luas kepada anak dan sesuai dengan tujuan pendidikan nasional. Kebiasaan menonton televisi pendidikan dapat dilihat dari seberapa sering anak menonton program-program siaran televisi pendidikan sekolah dan sepanjang masa di jam-jam setelah pulang sekolah dan hari Minggu.

Pentingnya peran orang tua pada kebiasaan menonton televisi anak. Orang tua yang memiliki pola asuh yang tepat akan mengontrol anak tentang kebiasaan menonton 
televisi secara tepat pula. Orang tua yang baik akan membimbing anak untuk menonton televisi pendidikan karena anak cenderung meniru adegan televisi. Orang tua harus menerapkan pola asuh yang tepat agar anak tidak terjerumus dengan meniru adegan atau tokoh yang tidak mendidik.

Anak suka meniru hal-hal yang dilihat dari lingkungan sekitar. "Children are great imitators, modeling behavior they see, especially when the models are attractive and believable, whether in real life or on a screen." (Nucci \& Narvaez, 2008, p.540). Orang tua harus membimbing anak agar meniru hal-hal yang mendidik dari lingkungan sekitar. Anak dapat meniru perilaku orang tua sebagai lingkungan terdekat anak. Oleh karena itu, orang tua harus menjaga perilakunya agar dapat memberi contoh yang baik bagi anak. Anak dapat meniru adegan atau tokoh yang ditonton setiap hari dari program televisi. Peran orang tua sangat diperlukan dalam menerapkan pola asuh yang tepat sesuai dengan kebutuhan anak. Orang tua yang bijak dalam pengasuhan akan mengontrol anak untuk menonton televisi pendidikan agar anak mendapat pendidikan moral yang positif. Anak dapat belajar dan meniru nilai-nilai moral yang tersaji dalam program televisi pendidikan yang sering ditonton.

Penelitian ini bertujuan untuk mengetahui (1) hubungan antara pola asuh orang tua dengan nilai-nilai moral siswa kelas V SD se-Gugus Puren Condongcatur Depok Sleman, (2) hubungan antara kebiasaan menonton televisi pendidikan dengan nilai-nilai moral siswa kelas V SD se-Gugus Puren Condongcatur Depok Sleman, serta (3) hubungan secara bersama-sama antara pola asuh orang tua dan kebiasaan menonton televisi pendidikan dengan nilai-nilai moral siswa kelas V SD se-Gugus Puren Condongcatur Depok Sleman. Penelitian ini diharapkan dapat menghasilkan saran-saran yang dapat digunakan untuk acu an dalam meningkatkan nilai-nilai moral yang dimiliki anak terutama di lingkungan rumah.

\section{METODE}

Jenis Penelitian
Penelitian ini merupakan penelitian kuantitatif noneksperimental dengan desain penelitian korelasional. "Correlational research gathers data from individuals on two or more variables and then seeks to determine if the variables are related (correlated)." (Ary, 2010, p.27).

\section{Tempat dan Waktu Penelitian}

Penelitian ini dilaksanakan di kelas V SD se-Gugus Puren Condongcatur Depok Sleman tahun pelajaran 2015/2016. SD yang akan digunakan tempat penelitian di Gugus Puren Condongcatur Depok Sleman meliputi (1) SD Negeri Puren, (2) SD Negeri Ngringin, (3) SD Negeri Gejayan dan (4) SD Muhammadiyah Condongcatur. Kegiatan penelitian di sekolah dilakukan pada bulan Februari sampai dengan Maret 2016.

\section{Populasi dan Sampel Penelitian}

Populasi penelitian ini adalah seluruh siswa kelas V SD se-Gugus Puren Condongcatur Depok Sleman tahun ajaran 2015/2016 sebanyak 259 siswa. Daftar populasi penelitian kelas V disajikan pada Tabel 1.

Tabel 1. Daftar Populasi Penelitian

\begin{tabular}{|c|c|}
\hline Nama Sekolah Dasar & Banyaknya Siswa \\
\hline SD Negeri Puren & 37 \\
\hline SD Negeri Ngringin & 33 \\
\hline SD Negeri Gejayan & 26 \\
\hline $\begin{array}{c}\text { SD Muhammadiyah } \\
\text { Condongcatur }\end{array}$ & 163 \\
\hline Jumlah & 259 \\
\hline
\end{tabular}

Sumber: UPT Pelayanan Pendidikan Kecamatan Depok

Berdasarkan tabel yang dikembangkan oleh Isaac dan Michael (Sugiyono, 2010, p.128), dari jumlah populasi penelitian sebanyak 259 siswa diambil 149 siswa sebagai sampel penelitian dengan taraf kesalahan 5\%. Banyaknya sampel pada tiap-tiap kelas diambil atau ditentukan dengan teknik Proportionate Stratified Random Sampling karena populasi mempunyai jumlah anggota yang tidak homogen. Penentuan ukuran sampel penelitian di setiap kelas V SD disajikan dalam Tabel 2. 
Tabel 2. Jumlah Sampel Setiap Kelas V SD

\begin{tabular}{|c|c|c|}
\hline $\begin{array}{c}\text { Nama Sekolah } \\
\text { Dasar }\end{array}$ & Perhitungan & Sampel \\
\hline SD Negeri Puren & $\begin{array}{l}\text { "37" /"259" } \\
\text { "×149=21,88" }\end{array}$ & 21 \\
\hline $\begin{array}{l}\text { SD Negeri } \\
\text { Ngringin }\end{array}$ & $\begin{array}{l}\text { "33" /"259" } \\
\text { "×149=17,85" }\end{array}$ & 19 \\
\hline $\begin{array}{l}\text { SD Negeri Ge- } \\
\text { jayan }\end{array}$ & $\begin{array}{l}26 " / " 259 " \\
\text { "×149=14,4" }\end{array}$ & 15 \\
\hline $\begin{array}{l}\text { SD Muhammad- } \\
\text { iyah Condong- } \\
\text { catur }\end{array}$ & $\begin{array}{l}\text { "163" /"259" } \\
\text { "×149=93,87" }\end{array}$ & 94 \\
\hline \multicolumn{2}{|c|}{ Jumlah } & 149 \\
\hline
\end{tabular}

\section{Teknik dan Instrumen Pengumpulan Data}

Teknik pengumpulan data dalam penelitian ini adalah kuesioner. Kuesioner dilakukan dengan cara memberi seperangkat pernyataan tertulis kepada responden untuk dijawab. Kuesioner dipilih karena efisien dan praktis berdasarkan pertimbangan banyaknya jumlah sampel penelitian yang akan dijadikan subyek penelitian. Instrumen penelitian yang digunakan dalam penelitian korelasional ini adalah kuesioner. Kuesioner yang digunakan dalam penelitian ini meliputi kuesioner pola asuh orang tua, kebiasaan menonton televisi pendidikan dan nilai-nilai moral.

\section{Pengujian Instrumen Penelitian}

Pengujian instrumen penelitian ini adalah validitas dan reliabilitas. Validitas dalam penelitian ini adalah validitas konstruk (construct validity). Uji validitas konstruk digunakan pendapat dari ahli (expert judgement) kemudian dilakukan uji coba instrumen. Uji coba instrumen dilakukan pada populasi penelitian sebanyak 35 siswa. Setelah data ditabulasikan, pengujian dilanjutkan dengan analisis faktor. Teknik yang digunakan untuk menguji reliabilitas instrumen dalam penelitian ini yaitu menggunakan rumus Alpha.

\section{Teknik Analisis Data}

Teknik analisis data dalam penelitian ini meliputi analisis deskripsi, uji prasyarat analisis dan pengujian hipotesis. Skor masingmasing variabel penelitian dideskripsikan dalam analisis deskripsi. Uji prasyarat analisis dilakukan sebagai syarat sebelum dilakukan pengujian hipotesis. Rumus yang digunakan dalam pengujian hipotesis adalah rumus korelasi Pearson Product Moment dan korelasi ganda.

\section{HASIL DAN PEMBAHASAN Hasil}

Penelitian ini dilakukan pada siswa kelas V SD se-Gugus Puren Condongcatur Depok Sleman tahun pelajaran 2015/2016. Banyaknya siswa yang digunakan dalam penelitian ini berjumlah 149 siswa yang tersebar pada empat sekolah dasar. Empat sekolah dasar tersebut antara lain: (1) SD Negeri Puren, (2) SD Negeri Ngringin, (3) SD Negeri Gejayan dan (4) SD Muhammadiyah Condongcatur.

Pada variabel pola asuh orang tua, pola asuh tertinggi yang diterapkan pada siswa kelas V SD di gugus Puren Condongcatur Depok Sleman adalah pola asuh otoritatif, kedua pola asuh otoriter dan ketiga pola asuh permisif. Pola asuh otoritatif memiliki rata-rata 2,78; pola asuh otoriter memiliki rata-rata 2,47 dan pola asuh permisif memiliki rata-rata 2,28 . Pola asuh orang tua dalam mengasuh dan mendidik siswa kelas V SD se-Gugus Puren Condongcatur Depok Sleman tergolong tinggi yaitu dengan persentase terbanyak sebesar $23,5 \%$ yaitu 35 siswa. Histogram kategorisasi pola asuh orang tua terdapat pada Gambar 1.

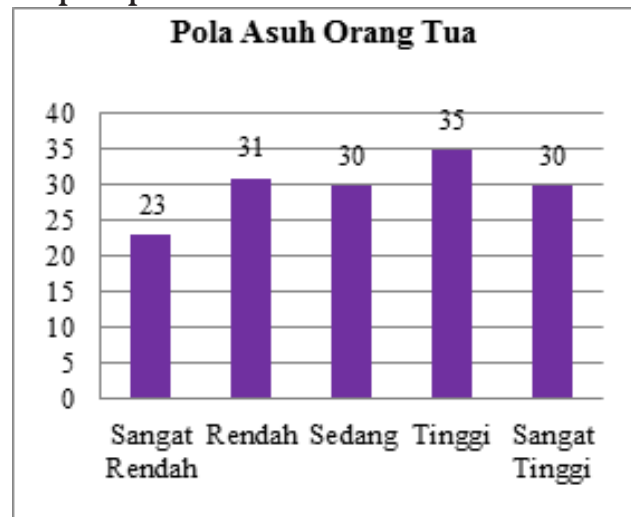

Gambar 1. Histogram Kategorisasi Pola Asuh Orang Tua

Pada variabel kebiasaan menonton televisi pendidikan, aspek kebiasaan menonton program-program siaran televisi pendidikan sepanjang masa memiliki rata-rata lebih tinggi daripada aspek kebiasaan menonton 
program-program siaran televisi pendidikan sekolah. Aspek kebiasaan menonton programprogram siaran televisi pendidikan sepanjang masa memiliki rata-rata sebesar 2,80 sedangkan aspek kebiasaan menonton programprogram siaran televisi pendidikan sekolah memiliki rata-rata sebesar 2,53. Kebiasaan menonton televisi pendidikan pada siswa kelas V SD se-Gugus Puren Condongcatur Depok Sleman tergolong sangat tinggi dengan persentase terbanyak sebesar 30,9\% yaitu 46 siswa. Histogram kategorisasi kebiasaan menonton televisi pendidikan terdapat pada Gambar 2 .

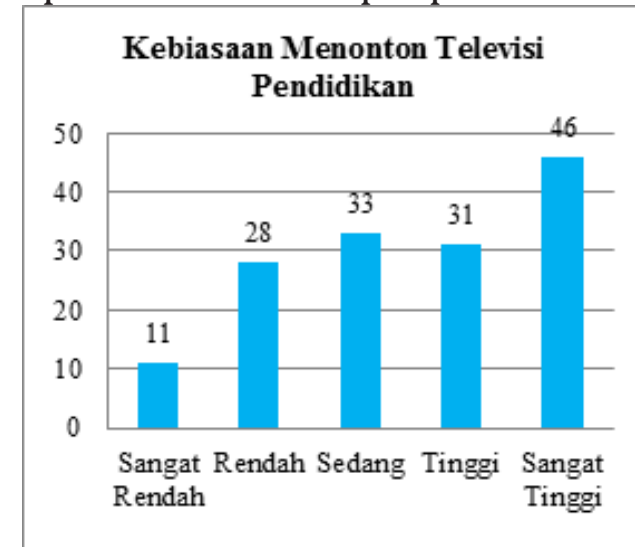

Gambar 2. Histogram Kategorisasi Kebiasaan Menonton Televisi Pendidikan

Pada variabel nilai-nilai moral, aspek tanggung jawab memiliki rata-rata lebih tinggi daripada aspek rasa hormat. aspek tanggung jawab memiliki rata-rata sebesar 3,01 sedangkan aspek rasa hormat memiliki rata-rata sebesar 2,93. Nilai-nilai moral pada siswa kelas V SD se-Gugus Puren Condongcatur Depok Sleman tergolong sangat tinggi yaitu dengan persentase terbanyak sebesar $34,2 \%$ yaitu 51 siswa. Histogram kategorisasi nilai-nilai moral terdapat pada Gambar 3.

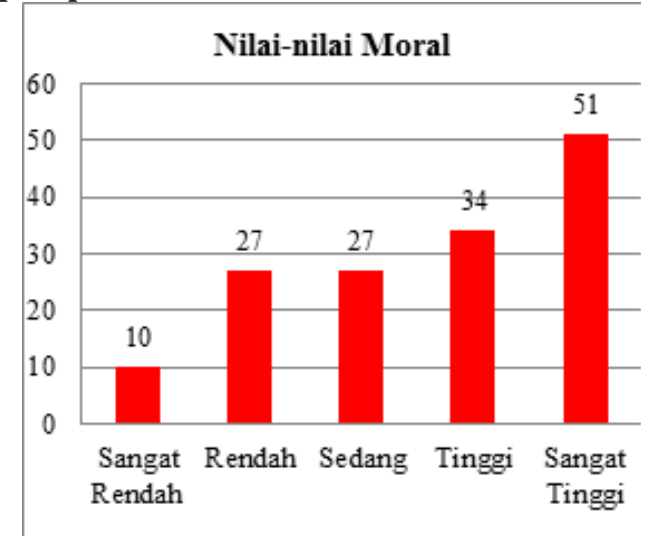

Gambar 3. Histogram Kategorisasi Nilai-nilai Moral
Hipotesis Pertama (Hubungan antara Pola Asuh Orang Tua dengan Nilai-nilai Moral)

Hasil pengujian menggunakan korelasi Product Moment antara pola asuh orang tua dengan nilai-nilai moral sebesar 0,812 (r hitung). Kemudian 0,812 (r hitung) dikonsultasikan dengan 0,159 ( $\mathrm{r}$ tabel) maka $\mathrm{r}$ hitung $0,812>r$ tabel 0,159. Nilai signifikansi antara variabel pola asuh orang tua dengan nilai-nilai moral siswa sebesar 0,000. Nilai signifikansi 0,000 lebih kecil dari tingkat ? ?yang digunakan $(0,05)$ atau dapat ditulis 0,000 0,05. Tingkat keeratan hubungan mempunyai tingkat hubungan yang baik karena terletak antara nilai $0,66-0,85$.

Berdasarkan analisis yang telah dilakukan maka hipotesis pertama ini dapat diterima. Dengan demikian, terdapat hubungan yang positif dan signifikan antara pola asuh orang tua dengan nilai-nilai moral siswa kelas V SD se-Gugus Puren Condongcatur Depok Sleman. Hasil analisis hubungan antara pola asuh orang tua dengan nilai-nilai moral siswa menggunakan program SPSS 16 for windows tersaji pada Tabel 3.

Tabel 3. Analisis Hubungan antara Pola Asuh Orang Tua dengan Nilai-nilai Moral

\begin{tabular}{|c|l|l|l|c|}
\hline \multirow{2}{*}{$\mathbf{R}$} & \multicolumn{4}{|c|}{ Change Statistics } \\
\cline { 2 - 5 } & $\begin{array}{c}\text { R Square } \\
\text { Change }\end{array}$ & $\begin{array}{l}\text { F } \\
\text { Change }\end{array}$ & $\begin{array}{l}\text { df1 } \\
\text { df2 }\end{array}$ & $\begin{array}{c}\text { Sig. F } \\
\text { Change }\end{array}$ \\
\hline $812 \mathrm{a}$ & .660 & 285.342 & 1 & 147 \\
\hline
\end{tabular}

a. Predictors: (Constant), Pola asuh orang tua

Hipotesis Kedua (Hubungan antara Kebiasaan Menonton Televisi Pendidikan dengan Nilainilai Moral)

Hasil pengujian menggunakan korelasi Product Moment antara kebiasaan menonton televisi pendidikan dengan nilai-nilai moral sebesar 0,731 ( $r$ hitung). Kemudian 0,731 (r hitung) dikonsultasikan dengan 0,159 ( $\mathrm{r}$ tabel) maka $r$ hitung 0,731 > r tabel 0,159. Nilai signifikansi antara variabel kebiasaan menonton televisi pendidikan dengan nilai-nilai moral siswa sebesar 0,000. Nilai signifikansi 0,000 lebih kecil dari tingkat ? ?yang digunakan 
$(0,05)$ atau dapat ditulis $0,000<0,05$. Tingkat keeratan hubungan mempunyai tingkat hubungan yang baik karena terletak antara nilai $0,66-0,85$.

Berdasarkan analisis yang telah dilakukan maka hipotesis kedua ini dapat diterima. Dengan demikian, terdapat hubungan yang positif dan signifikan antara kebiasaan menonton televisi pendidikan dengan nilai-nilai moral siswa kelas V SD se-Gugus Puren Condongcatur Depok Sleman. Hasil analisis hubungan antara kebiasaan menonton televisi pendidikan dengan nilai-nilai moral siswa menggunakan program SPSS 16 for windows tersaji pada Tabel 4.

Tabel 4. Analisis Hubungan antara Kebiasaan Menonton Televisi Pendidikan dengan Nilai-nilai Moral

\begin{tabular}{|c|c|l|l|c|}
\hline \multirow{2}{*}{ R } & \multicolumn{4}{|c|}{ Change Statistics } \\
\cline { 2 - 5 } & $\begin{array}{c}\text { R Square } \\
\text { Change }\end{array}$ & $\begin{array}{l}\mathbf{F} \\
\text { Change }\end{array}$ & $\begin{array}{l}\text { df1 } \\
\text { df2 }\end{array}$ & $\begin{array}{c}\text { Sig. F } \\
\text { Change }\end{array}$ \\
\hline $.731 \mathrm{a}$ & .535 & 168.882 & $\begin{array}{l}1 \\
147\end{array}$ & .000 \\
\hline
\end{tabular}

a. Predictors: (Constant), Kebiasaan menonton televisi pendidikan

Hipotesis Ketiga (Hubungan antara Pola Asuh Orang Tua dan Kebiasaan Menonton Televisi Pendidikan dengan Nilai-nilai Moral)

Hasil pengujian menggunakan korelasi ganda antara pola asuh orang tua dan kebiasaan menonton televisi pendidikan dengan nilainilai moral sebesar 0,841 ( $r$ hitung). Kemudian 0,841 ( $\mathrm{r}$ hitung) dikonsultasikan dengan 0,159 ( $\mathrm{r}$ tabel) maka $\mathrm{r}$ hitung 0,841 > $\mathrm{r}$ tabel 0,159. Pengujian signifikansi menggunakan uji $\mathrm{F}$, sehingga diperoleh $\mathrm{F}$ hitung sebesar 176,828. Harga tersebut dibandingkan dengan $\mathrm{F}$ tabel dengan $\mathrm{dk}$ pembilang $=2 \mathrm{dan} \mathrm{dk}$ penyebut $=$ $149-2-1=146$, untuk kesalahan 5\% maka harga $F$ tabel adalah 3,06. Dengan demikian, F hitung 176,828 > F tabel 3,06. Tingkat keeratan hubungan mempunyai tingkat hubungan yang baik karena terletak antara nilai 0,66-0,85.

Berdasarkan analisis yang telah dilakukan maka hipotesis ketiga ini dapat diterima. Dengan demikian, secara bersama-sama terdapat hubungan yang positif dan signifikan an- tara pola asuh orang tua dan kebiasaan menonton televisi pendidikan dengan nilai-nilai moral siswa kelas V SD se-Gugus Puren Condongcatur Depok Sleman. Hasil analisis hubungan antara pola asuh orang tua dan kebiasaan menonton televisi pendidikan dengan nilai-nilai moral siswa menggunakan program SPSS 16 for windows tersaji pada Tabel 5.

Tabel 5. Analisis Hubungan antara Pola Asuh Orang Tua dan Kebiasaan Menonton Televisi Pendidikan dengan Nilai-nilai Moral

\begin{tabular}{|c|l|l|l|c|}
\hline \multirow{2}{*}{$\mathbf{R}$} & \multicolumn{4}{|c|}{ Change Statistics } \\
\cline { 2 - 5 } & $\begin{array}{c}\text { R Square } \\
\text { Change }\end{array}$ & $\begin{array}{l}\mathbf{F} \\
\text { Change }\end{array}$ & $\begin{array}{l}\text { df1 } \\
\text { df2 }\end{array}$ & $\begin{array}{c}\text { Sig. F } \\
\text { Change }\end{array}$ \\
\hline $841 \mathrm{a}$ & .708 & 176.828 & 2 & 146 \\
.000 \\
\hline
\end{tabular}

a. Predictors: (Constant), Kebiasaan menonton televisi pendidikan, Pola asuh orang tua

\section{Pembahasan}

Hubungan antara Pola Asuh Orang Tua dengan Nilai-nilai Moral

Hasil penelitian menunjukkan bahwa terdapat hubungan yang positif dan signifikan antara pola asuh orang tua dengan nilai-nilai moral siswa. Dengan demikian, jika pola asuh orang tua semakin tinggi maka nilai-nilai moral pun semakin tinggi. Hasil tersebut dapat digeneralisasikan pada populasi siswa kelas V SD se-Gugus Puren Condongcatur Depok Sleman.

Hasil penelitian ini didukung oleh hasil penelitian Lacny (2015). Penelitian tersebut menunjukkan bahwa terdapat korelasi antara pola asuh orang tua dengan perkembangan moral anak. Pola asuh orang tua yang diterapkan berpengaruh terhadap nilai-nilai moral yang dimiliki anak. Pola asuh yang baik adalah pola asuh yang tepat sesuai dengan kebutuhan anak dalam memberikan kontrol dan respon terhadap anak. Orang tua yang baik adalah orang tua yang terlibat dalam pengasuhan dan pendidikan moral anak. Orang tua tidak hanya mendidik anak menjadi pandai tetapi memiliki nilai-nilai moral yang baik.

Pola asuh otoritatif yang paling banyak diterapkan dalam penelitian ini memberi banyak manfaat positif bagi anak. "Children of 
authoritative families tend to be independent, self-reliant, and responsible and to have prosocial behaviors, such as cooperation, sharing, and sympathy for others." (Grant \& Ray, 2013, p.63). Semakin tinggi orang tua terlibat dalam pengasuhan, sehingga semakin tinggi pula nilai-nilai moral anak. Orang tua lebih banyak terlibat langsung dalam mengasuh dan mendidik anak sesuai dengan kebutuhan anak, sehingga memberi banyak manfaat positif bagi perkembangan anak termasuk nilai-nilai moral yang dimiliki anak. Hal tersebut dapat dilihat dari tingginya pola asuh orang tua dan nilainilai moral anak.

\section{Hubungan antara Kebiasaan Menonton Televisi} Pendidikan dengan Nilai-nilai Moral

Hasil penelitian menunjukkan bahwa terdapat hubungan yang positif dan signifikan antara kebiasaan menonton televisi pendidikan dengan nilai-nilai moral siswa. Dengan demikian, jika kebiasaan menonton televisi pendidikan semakin tinggi maka nilai-nilai moral pun semakin tinggi. Hasil tersebut dapat digeneralisasikan pada populasi siswa kelas V SD se-Gugus Puren Condongcatur Depok Sleman.

Anak meniru nilai-nilai moral yang tersaji dalam program-program televisi pendidikan. "Models in the media can have an impact as well. Rather than encouraging aggression, some characters in popular media promote prosocial behaviors-those aimed at helping others rather than at enhancing one's personal well-being." (Ormrod, 2012, p.124). Anak cenderung belajar melalui tontonan yang dilihat di televisi. Tingginya tingkat kebiasaan anak menonton televisi pendidikan memberi manfaat positif berupa tingginya tingkat nilai-nilai moral anak. Anak belajar dan meniru nilai-nilai moral dari program televisi pendidikan yang ditontonnya setiap hari.

Anak terbiasa menonton televisi pendidikan setiap hari. Tingkat kebiasaan anak menonton televisi tinggi sehingga tingkat nilainilai moral yang dimiliki anak pun tinggi. "In fact, the small screen has become a kind of teacher or a window to the world through which children are watching continuously and from which they extract values and models of behaviour that can be used as references in their daily lives." (Martinez \& Lopez, 2011, p.33). Dari kebiasaan anak menonton televisi pendidikan setiap hari maka anak semakin banyak belajar dan meniru nilai-nilai moral yang tersaji. Anak yang terbiasa menonton program-program televisi pendidikan belajar melalui adegan atau model yang diidolakan. Anak meniru adegan atau model yang mengandung nilai-nilai moral sehingga anak bisa menerapkan nilai-nilai moral yang didapat dari program-program televisi pendidikan yang ditontonnya.

Hubungan antara Pola Asuh Orang Tua dan Kebiasaan Menonton Televisi Pendidikan dengan Nilai-nilai Moral

Hasil penelitian menunjukkan bahwa terdapat hubungan yang positif dan signifikan antara pola asuh orang tua dan kebiasaan menonton televisi pendidikan dengan nilai-nilai moral siswa. Dengan demikian, jika pola asuh orang tua dan kebiasaaan menonton televisi pendidikan semakin tinggi maka nilai-nilai moral pun semakin tinggi. Hasil tersebut dapat digeneralisasikan pada populasi siswa kelas $\mathrm{V}$ SD se-Gugus Puren Condongcatur Depok Sleman.

Anak suka belajar dan meniru hal-hal yang dilihat dari lingkungan sekitar. "Children are great imitators, modeling behavior they see, especially when the models are attractive and believable, whether in real life or on a screen." (Nucci \& Narvaez, 2008, p.540). Anak belajar dan meniru nilai-nilai moral yang diajarkan dan dicontohkan orang tua dalam pengasuhan. Anak belajar dan meniru nilai-nilai moral yang tersaji dalam program televisi pendidikan yang ditontonnya setiap hari. Hal tersebut dapat terlihat dari tingginya pola asuh orang tua, kebiasaan menonton televisi pendidikan dan nilai-nilai moral.

Orang tua menerapkan pola asuh yang tepat sesuai dengan kebutuhan anak. Orang tua banyak terlibat secara langsung dalam mendidik dan mengasuh anak termasuk dalam kebiasaan anak menonton televisi pendidikan. "Children usually watch what their parents 
watch." (Bergin \& Bergin, 2012, p.576). Orang tua mengontrol dan memberi perhatian terhadap anak. Orang tua mengontrol kebiasaan anak dalam menonton televisi pendidikan dengan membimbing dan memberi contoh program televisi yang seharusnya ditonton.

Orang tua mendidik moral anak dari program televisi pendidikan yang mengandung nilai-nilai moral. "It is clear that children can learn from educational media. Television programs designed with a specific goal to teach academic or social skills can be effective with potentially long-lasting effects." (Kirkorian, Wartella \& Anderson, 2008, p.47). Orang tua mengontrol perilaku anak dengan mengarahkan nilai-nilai moral yang dapat ditiru dari program televisi pendidikan. Anak dapat mempelajari nilai-nilai moral yang tersaji dalam program televisi pendidikan yang ditonton sehingga nilai-nilai moral tersebut dapat dijadikan aturan dalam bersosialisasi.

\section{SIMPULAN}

Berdasarkan analisis data dan pembahasan tentang hubungan antara pola asuh orang tua dan kebiasaan menonton televisi pendidikan dengan nilai-nilai moral siswa, dapat diambil kesimpulan bahwa: (1) Terdapat hubungan yang positif dan signifikan antara pola asuh orang tua dengan nilai-nilai moral siswa kelas V SD se-Gugus Puren Condongcatur Depok Sleman. Dimana $r$ hitung $=0,812$ sedangkan $r$ tabel $=0,159$ sehingga $r$ hitung $>$ $r$ tabel. Nilai signifikansi yang diperoleh yaitu sebesar 0,000 sehingga 0,000 lebih kecil dari tingkat yang digunakan $(0,05)$ atau dapat ditulis $0,000<0,05$. (2) Terdapat hubungan yang positif dan signifikan antara kebiasaan menonton televisi pendidikan dengan nilai-nilai mo ral siswa kelas V SD se-Gugus Puren Condongcatur Depok Sleman. Dimana $r$ hitung $=0,731$ sedangkan $r$ tabel $=0,159$ sehingga $r$ hitung $>$ $r$ tabel. Nilai signifikansi yang diperoleh yaitu sebesar 0,000 sehingga 0,000 lebih kecil dari tingkat yang digunakan $(0,05)$ atau dapat ditulis $0,000<0,05$. (3) Terdapat hubungan yang positif dan signifikan antara pola asuh orang tua dan kebiasaan menonton televisi pendi- dikan dengan nilai-nilai moral siswa kelas V SD se-Gugus Puren Condongcatur Depok Sleman. Dimana $r$ hitung $=0,841$ sedangkan $r$ tabel $=$ 0,159 sehingga $r$ hitung $>r$ tabel. Diketahui F hitung sebesar 176,828 sedangkan $F$ tabel untuk kesalahan $5 \%$, dk pembilang $=2$ dan $\mathrm{dk}$ penyebut $=146$ adalah 3,06. Dengan demikian $\mathrm{F}$ hitung lebih besar dari $\mathrm{F}$ tabel ( $\mathrm{F}$ hitung $176,828>$ F tabel 3,06).

\section{UCAPAN TERIMA KASIH}

Kami ucapkan terima kasih kepada para informan yang terlibat dalam penelitian ini, terutama para guru dan 149 siswa kelas V SD se-Gugus Puren Condongcatur Depok Sleman, sehingga penelitian ini dapat berjalan dengan baik. Selain itu kami ucapkan terima kasih kepada pihak-pihak yang turut membantu support dana sehingga penelitian ini dapat berjalan dengan lancar. Terima kasih kepada redaksi yang telah mempublikasikan artikel hasil penelitian ini.

\section{DAFTAR PUSTAKA}

Akinsola, E.F., (2011). Relationship between parenting style, family type, personality dispositions and academic achievement of young people in Nigeria. Ife PsychologIA, 19 (2), 246-267.

Allen, J. \& Dennis, M. (2009). Dignity and respect matter. British Journal of Healthcare Assistants, 3 (12), 594-598.

Alloway, T.P., Williams, S., Jones, B., et al. (2013). Exploring the impact of television watching on vocabulary skills in toddlers. Early Childhood Education Journal, 42, 343-349.

Apriani, A., \& Wangid, M. (2015). Pengaruh SSP tematik-integratif terhadap karakter disiplin dan tanggung jawab siswa kelas III SD. Jurnal Prima Edukasia, 3(1), 12-25. Retrieved from http://journal.uny.ac.id/index.php/jpe/article/view/4061

Ary, D., Jacobs, L.C., \& Sorensen, C. (2010). Introduction to research in education 8th ed.). Wadsworth: Cengage Learning.

Bergin, C.C. \& Bergin, D.A. (2012). Child and adolescent development in your classroom. Wadsworth: Cengage Learning. 
Darmayanti, S., \& Wibowo, U. (2014). Evaluasi program pendidikan karakter di Sekolah Dasar Kabupaten Kulon Progo. Jurnal Prima Edukasia, 2(2), 223-234. Retrieved from http://journal.uny.ac.id/index.php/jpe/article/view/2721

Darwanto. (2011). Televisi sebagai media pendidikan. Yogyakarta: Pustaka Pelajar.

Grant, K. B. \& Ray, J. A. (2013). Home, school, and community collaboration: culturally responsive family engagement (2nd ed.). California: SAGE Publications, Inc.

Kirkorian, H.L., Wartella, E.A. \& Anderson, D.R. (2008). Media and young children's learning. The Future of Children, 18 (1), 39-61.

Lacny, A.M. (2015). Firefighters as key public servants: Does parenting correlate with moral development? Disertasi doktor, tidak diterbitkan, Capella University, Minneapolis, United States.

Levine, L.E. \& Munsch, J. (2014). Child development an active learning approach (2nd ed.). California: SAGE Publications, Inc.

Lickona, T. (2013). Mendidik untuk membentuk karakter: bagaimana sekolah dapat mengajarkan sikap hormat dan tanggung jawab. (Terjemahan Juma Abdu Wamaungo). Jakarta: Bumi Aksara. (Buku asli diterbitkan tahun 1989).

Martinez, A.F. \& Lopez, M.C.L.d.A. (2011). Television and children: five years after the self-regulation code. Revista Latina de Communicacion Social, 66, 31-62.

Nucci, L.P. \& Narvaez, D. (2008). Handbook of moral and character education. New York: Routledge.

Ormrod, J.E. (2012). Human learning (6th ed.). New Jersey: Pearson Education, Inc.

Papalia, D.E. \& Feldman, R.D. (2015). Menyelami perkembangan manusia (Edisi 12). (Terjemahan Fitriana Wuri Herarti). Jakarta: Salemba Humanika. (Buku asli diterbitkan tahun 2014).

Poerwanti, E. (2013). Sistem indikator nilainilai moral universal sebagai evaluasi reflektif pendidikan karakter di TK. Jurnal Prima Edukasia, 1(1), 30-42. Retrieved from http://journal.uny.ac.id/index.php/jpe/article/view/2314

Republik Indonesia. (2003). Undang-Undang Republik Indonesia Nomor 20, Tahun 2003, tentang Sistem Pendidikan Nasional.

Sugiyono. (2010). Metode penelitian pendidikan (pendekatan kuantitatif, kualitatif, dan R\&D). Bandung: Alfabeta. 